\title{
FENOMEN „PAŃSTWA ISLAMSKIEGO” I JEGO ŹRÓDLA
}

Słowo „fenomen” występuje w języku polskim w kilku podstawowych znaczeniach. Pierwsze spośród nich podkreśla, że jest to ,rzadkie, niezwykłe zjawisko; rzecz wyjątkowa, zadziwiająca”. Inne wskazuje natomiast na ,zjawisko fizyczne lub psychiczne będące przedmiotem poznania” lub „każdy fakt empiryczny będący punktem wyjścia badań naukowych" (Stownik, 1978: 580). Każde z zaprezentowanych powyżej znaczeń może być zastosowane w odniesieniu do „Państwa Islamskiego"1 (PI) i analizy jego spektakularnych sukcesów występujących zarówno w płaszczyźnie politycznej oraz militarnej, ale także finansowej, logistycznej czy propagandowej. Jest to tym bardziej znamienne, iż rozpatrując genezę „Państwa Islamskiego” oraz organizacji poprzedzających jego powstanie, kilkukrotnie wskazać można na wydarzenia, które doprowadziły do prawie całkowitego rozbicia analizowanego ruchu islamistycznego. Z taką sytuacją mieliśmy do czynienia choćby w latach 2006-2009, kiedy to jego struktura została niemalże unicestwiona czy w 2011 r., kiedy armia iracka aresztowała kilku czołowych przywódców ruchu (Izak, 2016: 84). Pomimo tego „Państwo Islamskie” oraz jego protoplaści wykazali się dużą zdolnością do reorganizacji oraz dostosowania się do dynamicznie zmieniających się tak wewnętrznych, jak i międzynarodowych realiów. Szybko pozyskali ochotników, broń oraz środki finansowe, a także związane z tym wpływy i znaczenie. Było to duże zaskoczenie zarówno dla wielu polityków, jak i analityków bliskowschodniej sceny politycznej.

Za ważny moment przełomowy uznać należy utworzenie w czerwcu 2014 r. kalifa$\mathrm{tu}^{2}$. W szczytowym okresie swojej potegi „Państwo Islamskie” kontrolowało obszar o powierzchni porównywalnej do dwóch trzecich terytorium Polski, podejmując ponadto bezpośrednie lub pośrednie działania w wielu innych częściach świata na przykład w: Libii, Tunezji, Afganistanie, Nigerii czy Jemenie, często wykorzystując w tym celu lokalne organizacje lub grupy islamistyczne.

Wbrew częstym, obiegowym opiniom „Państwo Islamskie” w rozumieniu prawa międzynarodowego oraz praktyki międzynarodowej nie jest państwem. Choć posiada takie elementy, jak: terytorium, ludność oraz struktury władzy, nie ma jednak zdolności do utrzymywania stosunków międzynarodowych oraz nie spełnia wymogu tzw. zewnętrznej suwerenności. Spełnienie wszystkich tych kryteriów warunkuje państwowość.

\footnotetext{
1 Stosowane są także inne nazwy lub akronimy np. ISIS, ISIL, DAESH, Państwo Muzulmańskie, zob. np.: Dawn, 2014; Hall, 2015; Hanne, Flichy de La Neuville, 2015.

2 Podkreślić należy, że nie była to pierwsza próba stworzenia ,państwa muzułmańskiego". Wcześniejsze dotyczyły np. Somalii, Mali czy Afganistanu (Wejkszner, 2016).
} 
Można zatem mówić jedynie o pewnych elementach państwowości, ale nie o państwie jako podmiocie prawa międzynarodowego czy stosunków międzynarodowych.

„Państwo Islamskie” jest nową, a zarazem nowoczesną formą aktywności terrorystycznej. Wykracza poza klasyczne rozumienie organizacji terrorystycznej, kontrolując ponadpaństwowe terytorium czy dysponując rozbudowanymi strukturami realizującymi jego cele. „Państwo Islamskie” to hybrydowa struktura terrorystyczna, która łączy cechy przypisywane: organizacji terrorystycznej, grupie przestępczej, państwu, sieci terrorystycznej czy formacji zbrojnej. Jest to zatem najbardziej złożony element tzw. odwróconej piramidy terrorystycznej.

\section{Schemat 1. Model odwróconej piramidy terrorystycznej}

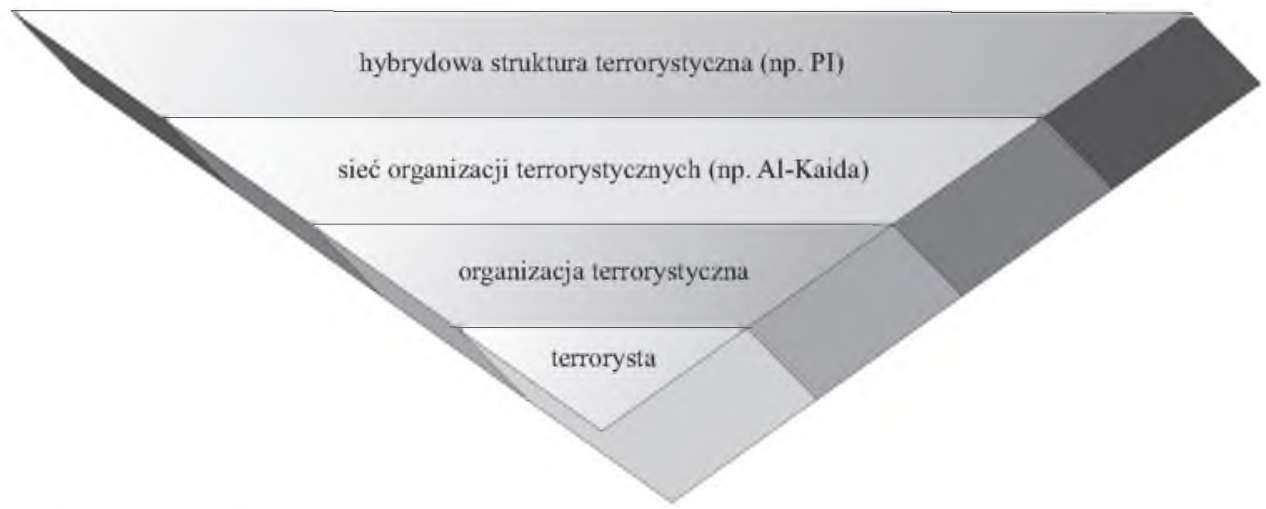

Źródlo: Opracowanie własne.

Zasadniczym celem tekstu jest wskazanie oraz usystematyzowanie najważniejszych przyczyn, które doprowadziły do gwałtownego wzrostu siły oraz znaczenia „Państwa Islamskiego"3. Są one sumą składową wielu różnorakich i ściśle powiązanych ze sobą czynników. Na przykład zdaniem W. Rudischhauser kluczową rolę odegrały w tym przypadku cztery czynniki, takie jak:

- przejęcie przez PI kontroli nad dużym terytorium;

- uzyskanie bardzo znaczących środków finansowych;

- umiejętne wykorzystanie mediów społecznościowych;

- zwerbowanie tysięcy bojowników pochodzących zarówno z państw muzułmańskich, jak i „zachodnich”. Co istotne, część spośród ochotników to osoby posiada-

3 Sukcesy „Państwa Islamskiego” rozpatrywane są z uwzględnieniem faktu, iż od 2015 roku sukcesywnie traci ono inicjatywę oraz kontrolowane przez siebie terytorium. Porażki te są konsekwencją wielu powiązanych ze sobą czynników, takich jak choćby: zintensyfikowanie nalotów prowadzonych przez siły koalicji międzynarodowej pod przywództwem USA, operacja wojskowa Federacji Rosyjskiej i jej wsparcie udzielane siłom prezydenta Baszara al-Asada, dzialania irackiej armii rządowej. bojowników kurdyjskich czy innych podmiotów walczących z PI. Są one związane także m.in. ze spadkiem dostępnych przez PI środków finansowych (np. wedhug amerykańskich ekspertów dochody ze sprzedaży ropy zmniejszyly się od października 2015 r. do stycznia 2016 r. o około 30\%), ograniczeniem liczby nowych rekrutów czy innymi działaniami podejmowanymi wobec PI przez społeczność międzynarodową (Gaier, 2016). 
jące wiedzę i doświadczenie np. w zakresie wojskowości, nauk ścisłych, inżynierii, medycyny, informatyki, marketingu itp. (Rudischhauser, 2015).

Alternatywne i częściowo podobne zestawienie czynników, które doprowadzily do powstania oraz późniejszych sukcesów „Państwa Islamskiego” zaprezentował autor opracowania zamieszczonego na łamach czasopisma „Dziennik.pl” (10 blędów, 2015). Obejmuje ono dziesięć następujących elementów:

- zawarcie porozumienia określanego mianem „bliskowschodniej Jałty”, zostało ono podpisane na przełomie 1915 i 1916 r. przez Francję oraz W. Brytanię i doprowadziło do podziału Bliskiego Wschodu na strefy wpływów, czego konsekwencje występują po dzień dzisiejszy:

- destabilizacja sytuacji w regionie, związana przede wszystkim z obaleniem rządów Saddama Husajna, co zmieniło także układ sił na Bliskim Wschodzie;

- niedotrzymanie przez amerykańską administrację obietnic dotyczących podziału po wojnie władzy pomiędzy irackich szyitów i sunnitów, co spowodowało rozgoryczenie części sunnitów i ich wsparcie dla „Państwa Islamskiego”;

- błędna polityka irackiego premiera N. al-Malika, który nie respektował zasad związanych z podziałem władzy pomiędzy największe grupy etniczno-religijne, towarzyszyły temu częste przypadki prześladowania sunnitów;

- pozostawienie w Iraku przez siły USA dużych ilości broni, która z czasem została przekazana irackim siłom rządowym, a później na skutek porzucenia, kradzieży czy kupna trafiła do „Państwa Islamskiego”;

- sytuacja wewnętrzna w Syrii, związana z tzw. Arabską wiosną, konfliktem zbrojnym czy zaangażowaniem państw trzecich;

- zlekceważenie zagrożenia związanego z „Państwem Islamskim” przez zachodnie mocarstwa, w tym USA;

- długotrwały brak zaangażowania państw regionu w skuteczne zwalczanie „Państwa Islamskiego" oraz liczne przypadki wspierania jego działalności;

- radykalizacja $\mathrm{i}$ islamizacja $\mathrm{w}$ więzieniach, proces ten był realizowany w wielu więzieniach znajdujących się na Bliskim Wschodzie, w tym w miejscach znajdujących się pod amerykańską kontrolą, powyższa sytuacja wynikała zarówno z naruszeń praw czlowieka, jak i efektywnej indoktrynacji;

- skuteczne działania „Państwa Islamskiego" nie tylko o charakterze militarnym, ale także administracyjnym, logistycznym, propagandowym czy werbunkowym.

Przedstawione przyczyny sukcesów „Państwa Islamskiego” obejmują wiele różnych czynników. Podejmując próbę ich uporządkowania można je zakwalifikować do trzech głównych grup:

A. skuteczne wykorzystanie przez „Państwo Islamskie” siły twardej związanej zarówno z działaniami militarnymi, jak i atakami terrorystycznymi;

B. odpowiednie zastosowanie siły miękkiej, dotyczące na przykład sfery finansowej, logistycznej, werbunkowej czy propagandowej;

C. różne wydarzenia czy procesy o podłożu lokalnym lub międzynarodowym, które w większym lub mniejszym stopniu przyczyniły się do sukcesów PI.

Powyższe trzy elementy oraz zachodzące pomiędzy nimi interakcje tworzą system naczyń połączonych określany mianem triady fenomenu „Państwa Islamskiego” (TFPI). 


\section{Schemat 2. Triada fenomenu „Państwa Islamskiego"}

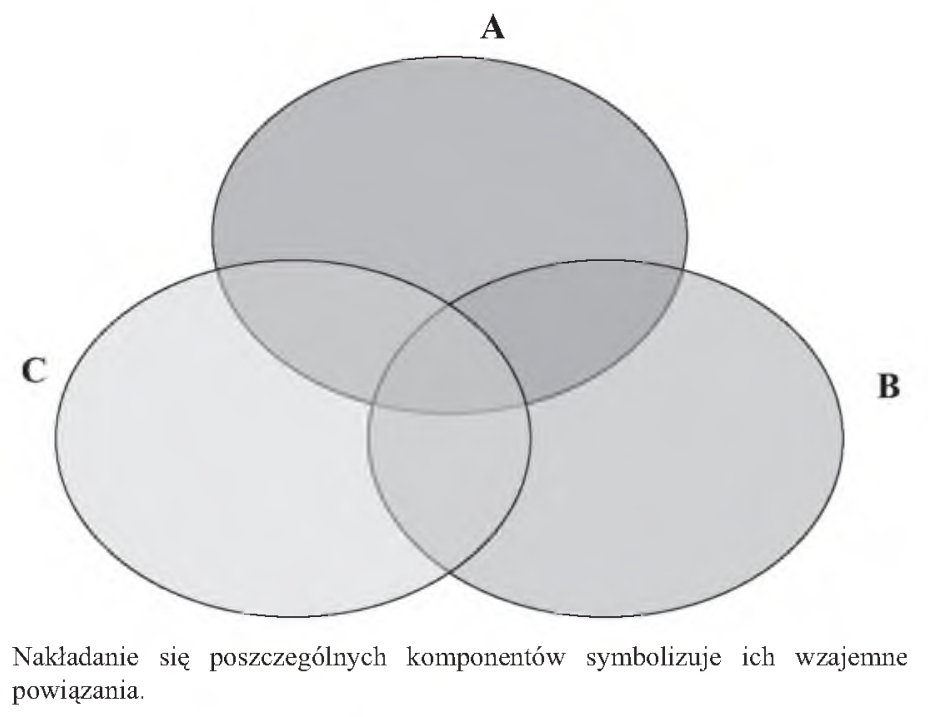

Źródlo: Opracowanie własne

\section{SILA TWARDA JAKO KOMPONENT FENOMENU „PAŃSTWA ISLAMSKIEGO”}

1. W pierwszej kolejności wskazać należy na działania zbrojne prowadzone przez bojowników "Państwa Islamskiego". Słyną oni z zaangażowania i okrucieństwa. W ocenie wielu ekspertów często są dobrze zorganizowani oraz umiejętnie dowodzeni. Reprezentują różne formacje, takie jak choćby: piechota, strzelcy wyborowi, odziały zwiadowcze, kwatermistrzowskie itp. Przykładem ich determinacji było zdobycie przez kilkuset bojowników w 2014 r. Mosulu, bronionego przez tysiące żołnierzy irackich (Todenhöfer, 2016: 44).

Szczególną pozycję wśród formacji zbrojnych PI odgrywa Amin - struktura zajmująca się wywiadem, kontrwywiadem i bezpieczeństwem. Zlecane są jej również porwania, zabójstwa i inne akty terroru. Podlega ona bezpośrednio kalifowi „Państwa Islamskiego" (Laurent, 2014).

2. Sukcesy „Państwa Islamskiego” w Iraku czy Syrii nie byłyby możliwe bez pozyskania dużej ilości różnorakiej broni oraz wyposażenia np. przejętego z magazynów obu państw. Znaczna część tego sprzętu została pozostawiona w Iraku przez siły USA, albo przekazana przez różne państwa syryjskiej opozycji. PI zwerbowało ponadto wielu oficerów i żołnierzy służących wcześniej w różnych miejscowych formacjach zbrojnych. Wykorzystało ich frustrację i niezadowolenie wynikające m.in. z braku pracy, środków do życia czy perspektyw, ale też utraty autorytetu i pozycji społecznej, prześladowań itp. Dzięki temu PI szybko i efektywnie zwiększyło swoją wartość bojową oraz udoskonaliło strategie stosowane na polu walki (Laurent, 2014). W przypadku Iraku dobrym tego odzwierciedleniem są słowa wypowiedziane przez generała J. Keane, 
byłego zasteppy szefa sztabu armii USA, który stwierdził: „ISIS jest wydatnie wspierane przez byłych zwolenników Saddama Husajna. Po obaleniu dyktatora to właśnie oni wzniecili powstanie. Mieli pieniądze, dysponowali znacznym kapitałem ludzkim, sporą ilością broni i amunicji, itd." (Hall, 2015: 26).

3. Stosowanie siły fizycznej połączone z brutalnością. J. Todenhöfer, przebywając wśród bojowników PI, skomentował to w sposób następujący: „Wydaje się jednak, że nawet legendarni peszmergowie boją się IS. Jak cała iracka armia. Strategia IS zrobiła swoje, szerząc strach i przerażenie brutalnymi, średniowiecznymi egzekucjami" (Todenhöfer, 2016: 49). Zespolenie siły fizycznej i brutalności dotyczy nie tylko działań militarnych, ale też ataków terrorystycznych oraz innych aktów terroru wymierzonych w przedstawicieli różnych grup religijnych, etnicznych czy politycznych. Świadczy o tym choćby przypadek spalenia w 2015 r. jordańskiego pilota czy egzekucja 21 koptyjskich chrześcijan. Jest to sygnał wysyłany zarówno do przeciwników, jak i sympatyków PI (w tym potencjalnych ochotników czy sponsorów). Ma on trafić również do innych radykalnych grup czy środowisk islamistycznych informując, iż to właśnie PI, a nie konkurencyjne organizacje (np. Al-Kaida), jest światowym „liderem w walce z niewiernymi”, dysponuje najszerszym arsenałem środków i najskuteczniej realizuje hasła dżihadu.

4. „Państwo Islamskie” dysponuje też trudnym do oszacowania arsenałem broni masowego rażenia, w tym na pewno broni chemicznej. W jego szeregach są wojskowi, jak i cywilni specjaliści z tego zakresu. Na podkreślenie zasługują przypadki użycia przez PI broni chemicznej. Do tej pory miały one jednak bardziej wydźwięk propagandowy niż militarny. Ich przykładem jest zastosowanie różnych środków chemicznych w okolicach Kobane czy gazu musztardowego oraz chloru w regionie Mahmur (Operacja, 2016: 27). W przyszłości, szczególnie w przypadku dalszych militarnych porażek PI, nie można wykluczyć szerszego zakresu użycia tej broni. Zagadnienie to rozpatrywać należy także $w$ kontekście ewentualnego użycia przez PI nie tylko środków chemicznych, ale również biologicznych, radiologicznych lub nuklearnych. Niepokojące w tym kontekście są doniesienia, że PI uzyskało dostęp do różnych rodzajów broni zarówno w Iraku, Syrii, jak i Libii (Rudischhauser, 2015).

\section{SILA MIĘKKA „PAŃSTWA ISLAMSKIEGO”}

1. „Państwo Islamskie” bardzo skutecznie wykorzystuje tzw. medialność terroryzmu (Wojciechowski, 2013). Polega ona na tym, iż wybierając określone cele ataku oraz stosując odpowiednie metody terroryści są świadomi, iż oprócz np. motywu zemsty czy zastraszenia mogą osiągnąc również „sukces” medialny. Będzie nim choćby długotrwałe czy zakrojone na szeroką skalę nagłośnienie ich działań oraz towarzyszących temu żądań. Służy temu również wykorzystywanie do celów propagandowych i komunikacyjnych mediów społecznościowych ${ }^{4}$. Do komunikowania się w internecie terro-

4 Jak szacuje Brookings Institute na początku 2015 roku do promowania PI wykorzystywano np. na Twitterze okolo 46 tys. kont. Z kolei niemiecki wywiad zagraniczny BND stoi na stanowisku, iż PI rozsyła dziennie (głównie za pomocą mediów spolecznościowych) od 30 do 40 filmów wideo, zdjęć czy pisemnych oświadczeń. 
ryści coraz częściej wykorzystują też technologie szyfrujące. Internet służy im także np. do sprzedaży książek, promocji filmów czy zbierania środków finansowych.

2. „Państwo Islamskie” lansuje popularne wśród czę́ści Muzułmanów hasło odrodzenia, które realizowane jest na kilku płaszczyznach. W sferze religijnej dotyczy ono „powrotu do źródel” i dosłownego interpretowania zapisów Koranu. Towarzyszy temu również wykorzystanie konfliktu pomiędzy sunnitami i szyitami oraz lansowanie idei „wojny z niewiernymi”. W płaszczyźnie politycznej odrodzenie przejawia się w utworzeniu kalifatu oraz budowaniu jego potegi politycznej, militarnej, ekonomicznej itp. Z kolei w wymiarze społecznym odrodzenie obejmuje odrzucenie dominacji i dyktatu tak „Świata zachodu”, jak i arabskich świeckich „dyktatur”.

Pomimo że w większości państw muzułmańskich poparcie dla PI utrzymuje się na ogół na poziomie kilku punktów procentowych (np.: Liban - 2\%, Egipt - 3\%, Zjednoczone Emiraty Arabskie - 3\%, Kuwejt - 4\%, Jordania - 4\%, Arabia Saudyjska - 5\%, Irak $-6 \%$, Jemen $-7 \%$, Libia - 8\%, Pakistan - 9\%), to jednak nie można go lekceważyć, zważywszy na fakt, iż w skali świata dotyczy ono kilku procent spośród prawie miliardowej społeczności sunnickiej.

3. Przejmując kontrolę nad obszarami w Iraku i Syrii oraz tworząc na nich własne instytucje „Państwo Islamskie” pozbawiło Al-Kaidę statusu kluczowej organizacji dżihadystycznej na świecie. W znacznym stopniu zagospodarowało zatem ,ideologiczną” oraz „logistyczną” próżnię, która powstała wraz ze spadkiem znaczenia Al-Kaidy. PI przejęło część jej wpływów, sponsorów, członków czy sympatyków. Wykazało się ponadto większą dynamiką, brutalnością czy inwencją. Zrobiło na „drodze terrorystycznej aktywności” przysłowiowy krok dalej, tworząc struktury państwowe oraz proklamując powstanie kalifatu. Taka decyzja miała głębokie przesłanie tak polityczne, ideologiczne, jak i religijne zważywszy na istotne znaczenie kalifatu w tradycji muzułmańskiej ${ }^{5}$. Doprowadziło to do konfrontacji pomiędzy „Państwem Islamskim” a Al-Kaidą dotyczącej nie tylko rywalizacji o pieniądze, bojowników czy sponsorów, ale też prestiż i popularność. Rywalizacja ta przybrała bardzo różne przejawy np.: walk w Syrii między PI a związaną wówczas z Al-Kaidą organizacją Front al-Nusra, sporów o autorstwo przeprowadzonych zamachów (np. atak w San Bernardino), konkurencji o wpływy m.in. w Afryce Północnej, Rogu Afryki czy na Bliskim Wschodzie, mordowania przywódców strony przeciwnej czy przypadków wzajemnego dyskredytowania się w mediach ${ }^{6}$.

W przyszłości nie można jednak wykluczyć scenariusza zakładającego, że oba terrorystyczne podmioty zaprzestaną rywalizacji oraz rozpoczną mniej lub bardziej skonsolidowaną współprace np. synchronizując i koordynując przeprowadzane ataki czy wymieniając się środkami, informacjami itp. Może to doprowadzić do powstania swoistej unii personalnej, a nawet nowej wspólnej struktury.

5 Na temat genezy, idei, oceny czy funkcjonowania kalifatu zob. np.: Wejkszner, 2016; Hanne, Flichy de La Neuville, 2015.

6 Przykładem, z jednej strony są oświadczenia Al-Kaidy nieuznające proklamowanego przez „Państwo Islamskie” kalifatu i stwierdzenia, że jest on „źródłem jątrzenia”. Z drugiej zaś strony m.in. artykuly zamieszczone w grudniowym (2015 r.) numerze „Dabiq” (publikacji „Państwa Islamskiego") krytykujące i szkalujące Al-Kaidę. Na temat podobieństw i różnic "Państwa Islamskiego" i Al-Kaidy zob. np.: Byman, 2016; Rocznik, 2015: 122; Hanne, Flichy de La Neuville, 2015. 
4. Jeszcze nigdy w historii żadna struktura terrorystyczna nie dysponowała tak wielkim kapitałem i związanymi z tym możliwościami działania. Jest to „zdolność pozyskiwania środków finansowych". Finanse PI w 2015 roku szacowano na $2-4$ mld \$ (Brisard, Martinez, 2016). Dla porównania inne struktury terrorystyczne miały następujące środki:

Tabela 1

Szacunkowe środki finansowe wybranych struktur terrorystycznych w $2015 \mathrm{r}$.

\begin{tabular}{||l|c|}
\hline \multicolumn{1}{|c|}{ Podmiot } & $\begin{array}{c}\text { Wysokość środków finanso- } \\
\text { wych w mln \$ }\end{array}$ \\
\hline Al-Kaida & $15-50$ \\
\hline Hamas & 70 \\
\hline FARC & 300 \\
\hline Hezbollah & $200-500$ \\
\hline Talibowie & 560 \\
\hline Państwo Islamskie & $2000-4000$ \\
\hline
\end{tabular}

Źródlo: International Business Times, MoneyJihad, CNN, „The Guardian”.

Pieniądze, którymi dysponuje PI pochodzą z bardzo różnorodnych źródeł, wśród których wymienić należy m.in.: sprzedaż ropy naftowej i gazu ziemnego ${ }^{7}$, zyski z kopalni fosforanów, zakładów przemysłowych czy uprawy zbóż, podatki i opłaty (np. podatek, którym obciążono niemuzułmanów, tzw. haracz drogowy, podatek od dóbr luksusowych), środki pochodzące z porwań dla okupu, darowizn, handlu dziełami sztuki, ludźmi i organami, wynajmu nieruchomości, kradzieży, przejęcia kontroli nad częścią lokalnych banków i ich aktywów ${ }^{8}$ itd.

5. PI jest nową formą aktywności terrorystycznej, która wykracza poza dotychczasowe zasady. Umiejętnie zespala aspekty: militarne, polityczne, ideologiczne, logistyczne, finansowe, społeczne, propagandowe itp. Jest to „zdolność organizacyjna”. „Państwo Islamskie" posiada rozbudowaną strukturę, która obejmuje różnego rodzaju instytucje $^{9}$ (Laurent, 2014) zajmujące się np.: administracją mediami, wywiadem, wymiarem sprawiedliwości, edukacją, opieką zdrowotną, pomocą charytatywną, ściąganiem podatków, surowcami naturalnymi, sprawami wojskowymi czy wypłacaniem świadczeń dla bojowników PI.

Dodatkowo w 2014 roku utworzono ministerstwo ds. męczenników, zajmujące się rekrutowaniem oraz szkoleniem kandydatów na zamachowców samobójców. Organ

7 Dla wielu państw dużym zaskoczeniem było bardzo szybkie tępo wznowienia przez PI wydobycia ropy naftowej na kontrolowanych terytoriach oraz jej dystrybucja na wielką skalę (Rocznik, 2015: 120).

8 Szacuje się, że tylko w Mosulu PI przejęlo aktywa bankowe wysokości okolo $400 \mathrm{mln} \$$ (Rocznik, 2015: 118; Brisard, 2014).

${ }_{9}$ Z instrukcji przygotowanej przez przywódców PI wynika, iż oprócz stworzenia różnych ministerstw zaplanowano także np. budowę koszar, opracowanie programu szkolenia dla dzieci i weteranów czy stworzenie zakładów zajmujących się produkcją i naprawą uzbrojenia. 
ten opiekuje się również ich rodzinami przekazując zapomogi czy renty. Innym sposobem „uhonorowania” terrorystów samobójców jest przyznawanie ich bliskim stanowisk publicznych czy celebrowanie tych osób podczas różnego rodzaju uroczystości.

6. Kolejna cecha to „zdolność werbunkowa”. Jest ona związana z umiejętnością pozyskiwania tak sympatyków, sponsorów, jak i bojowników pochodzących z bardzo różnych części świata. W szeregach PI walczą bojownicy pochodzących z około 70 państw, tak muzułmańskich, jak i niemuzułmańskich (Dodwell, Milton, Rassler, 2016). Ich łączną liczbę najczęściej szacuje się na 20-30 tys., z czego 3-5 tys. wywodzi się z Europy.

Wykres 1. Liczba bojowników pochodzących z wybranych państw, walczących w Syrii i Iraku (na milion osób)

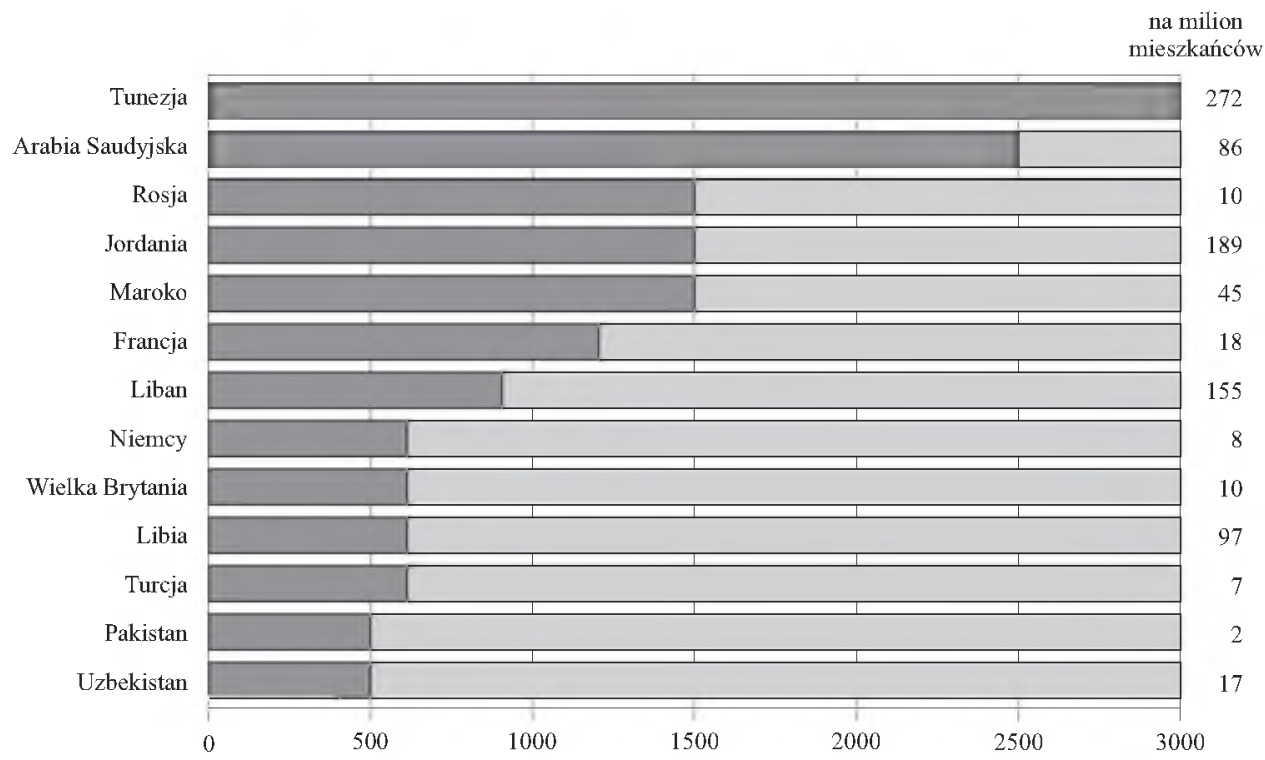

Nie uwzględniono państw, z których pochodzi mniej niz 500 bojowników

Źródlo: ICSR, CIA World Factbook, http://www.statysta.com, podaję za: „Rocznik Strategiczny” 2015, nr 16 (2016), Warszawa, s. 406.

Wśród sympatyków lub członków PI są przedstawiciele praktycznie wszystkich grup społecznych począwszy od uczniów i studentów, a kończąc na biznesmenach, prawnikach, nauczycielach, lekarzach czy inżynierach ${ }^{10}$. Osoby te bardzo często zapoznają się z ideologią PI poprzez internet. O popularności tej drogi komunikacji może świadczyć fakt, iż na przykład islamistyczny profil Al-Itisam subskrybowało ponad 50 tys. osób (Laurent, 2014).

10 Jak wynika z ustaleń zamieszczonych w książce pt. Engineers of Jihad: The Curious Connection between Violent Extremism and Education wśród 500 przeanalizowanych radykalnych islamistów, co drugi miał wyksztalcenie z zakresu inżynierii (Gambetta, Hertog, 2016). 
7. Ważną rolę odgrywa też strategia ${ }^{11}$ tworzenia ,nowych frontów walki” polegająca m.in. na podejmowaniu działań, w tym przeprowadzaniu zamachów terrorystycznych, w coraz to nowych państwach lub regionach. Strategia ta zaczerpnięta od Al-Kaidy została przez PI rozszerzona oraz udoskonalana. Obejmuje ona obecnie np.: Afganistan, Pakistan, Kaukaz, Czad, Kamerun, Somalię, Nigerie, Niger, Jemen, Filipiny, Indonezję, Malezję, Europę Zachodnią, Bałkany czy Palestynę (Łukasiewicz, 2016; Barfi, 2016).

\section{PRZYCZYNY SUKCESÓW „PAŃSTWA ISLAMSKIEGO” O PODLOŻU LOKALNYM LUB MIĘDZYNARODOWYM}

1. Różnorakie wydarzenia oraz procesy, które doprowadziły do wystapienia lub pogłębienia destabilizacji na Bliskim Wschodzie i tym samym znacząco ułatwily odniesienie przez PI tak znaczących sukcesów. Wśród nich wymienić należy przede wszystkim: konflikt palestyński, konflikt w Jemenie oraz Libii, rywalizacje ,wielkich mocarstw" o wplywy w regionie, kryzys irański, wydarzenia tzw. Arabskiej wiosny (Relations, 2015) i ich następstwa, zakończenie operacji ISAF w Afganistanie czy aktywizację środowisk islamistycznych w różnych częściach świata (Wejkszner, 2010).

2. Sytuacja występująca w Iraku oraz Syrii związana m.in. z: amerykańską interwencją w Iraku i późniejszą destabilizacją tego państwa, słabością irackiej władzy oraz struktur bezpieczeństwa, protestami części Irakijczyków przeciwko okupacji ich kraju, błędami popełnianymi przez irackie władze preferujące dominację określonej grupy religijnej, dalszym pogorszeniem się warunków życia w obu państwach, pogłębieniem się występujących tam antagonizmów wewnętrznych o charakterze religijnym, etnicznym czy politycznym, brutalizacją rządów, znaczącym obniżeniem siły bojowej armii obu państw, rozpadem irackiej oraz syryjskiej struktury państwowej, błędnym przeświadczeniem społeczności międzynarodowej o stopniowej stabilizacji sytuacji w Iraku i Syrii oraz szybkim rozbiciu PI ${ }^{12}$, zaangażowaniem państw trzecich (w tym bliskowschodnich) wspierających różne strony tak irackiego, jak i syryjskiego konfliktu.

3. „Państwo Islamskie”, w większym lub mniejszym stopniu, cieszy się poparciem nie tylko części społeczności muzułmańskiej, ale także licznych organizacji islamistycznych. Na przykład, jak wynika z analiz brytyjskiego Centrum Religii i Geopolityki obecnie w Syrii i Iraku działa co najmniej 15 fundamentalistycznych organizacji paramilitarnych liczących łącznie około 65 tys. członków. Część spośród nich współpracuje z PI. O skali poparcia dla PI ze strony innych organizacji islamistycznych świadczy również raport opublikowany przez ONZ, z którego wynika, iż do końca 2015 roku 34 ugrupowania islamistyczne na całym świecie przysięgły wierność „Państwu Islamskiemu" (ONZ, 2016).

11 Na temat innych strategii stosowanych przez PI zob.: Mironova, 2016.

12 Na przykład w czerwcu 2010 r. szef sil amerykańskich w Iraku generał R. Odierno w odniesieniu do PI stwierdzil: „80 procent ich przywódców nie żyje lub zostało schwytanych. Pozostali czują się pokonani!" 
4. Kolejnym kluczowym determinantem są spóźnione działania społeczności międzynarodowej (w szczególności wielkich mocarstw i ONZ) na rzecz kompleksowego ograniczenia źródeł finansowania „Państwa Islamskiego”. Znaczącą inicjatywą w tym zakresie była dopiero debata przeprowadzona 17 grudnia 2015 r. na forum Rady Bezpieczeństwa ONZ. Jej celem było wypracowanie i przyjęcie rezolucji uniemożliwiającej PI dostępu do międzynarodowego systemu finansowego oraz pozbawienie go zysków pochodzących m.in. z przemytu ropy, gazu czy antyków. Projekt rezolucji przygotowany wspólnie przez USA i Federację Rosyjską został przyjęty jednogłośnie. Zakłada on, że podmioty wspierające Al-Kaidę czy PI zostaną objęte systemem sankcji ONZ, takich jak choćby zamrożenie aktywów, zakaz wizowy czy wyprowadzenie embarga na broń. Nad realizacją przyjętych postanowień czuwa specjalny zespół ekspertów ONZ kontrolujących m.in. banki oraz inne instytucje finansowe państw członkowskich.

5. Do sukcesów PI w znacznym stopniu przyczyniły się również częste przypadki rozbieżnych interesów pomiędzy poszczególnymi państwami, a szczególnie tzw. wielkimi mocarstwami. Dobrze można to zobrazować na przykładzie relacji zachodzących na linii Federacja Rosyjska a koalicja, na czele której stoją Stany Zjednoczone ${ }^{13}$. Korzystne dla PI okazały się też animozje pomiędzy np.: Iranem, Turcją, Izraelem czy Arabią Saudyjską. Ich konkretnym przejawem są choćby: działania wojsk tureckich, utworzenie przez Arabią Saudyjską tzw. islamskiej koalicji antyterrorystycznej czy zabiegi dyplomatyczne Iranu, Izraela, Turcji itp. Inny aspekt to rywalizacja między Iranem a Arabią Saudyjską zarówno o wpływy w Syrii, Iraku czy Jemenie, jak i na całym obszarze bliskowschodnim. Rywalizacja ta ma nie tylko wymiar polityczny, ale również ekonomiczny (np. konkurencja o zyski pochodzące z ropy naftowej), jak i religijny (napięcia pomiędzy sunnicką Arabią Saudyjską a szyickim Iranem).

Przedstawione powyżej czynniki nie wyczerpują oczywiście pełnego spektrum przyczyn sukcesów „Państwa Islamskiego”. Wskazują one jednak na ich złożoność, wzajemne powiązania oraz różnorodność. Sukcesy PI są następstwem umiejętnego zespolenia oraz wykorzystania tak ,siły twardej” m.in. w postaci działań zbrojnych czy ataków terrorystycznych, jak i ,siły miękkiej”, związanej choćby ze sferą logistyczną, werbunkową, finansową czy propagandową. Znacząco wpłynęły na nie także wskazane w tekście wydarzenia czy procesy zachodzące w Iraku i Syrii oraz w innych częściach Bliskiego Wschodu.

Pomimo kurczenia się wpływów oraz zasobów „Państwo Islamskie” jeszcze długo będzie destabilizować sytuację międzynarodową i zagrażać bezpieczeństwu. Poznanie zatem źródeł jego sukcesów uznać należy za kwestę priorytetową, która może być pomocna nie tylko w pokonaniu PI, ale także uniknięciu w przyszłości wzrostu potegi innych organizacji islamistycznych czy terrorystycznych. Takie zagrożenie, w zróżnicowanym stopniu, występuje obecnie w różnych częściach świata, na przykład w: Algierii, Libii, Tunezji, Libanie, Jordanii, Palestynie, Nigerii, Czadzie, Nigrze, Somalii, Jemenie,

13 Uczestniczy w niej w różnym stopniu okolo 60 państw, z tego okolo 20 angażuje się w prowadzone operacje wojskowe. Przedstawiciele amerykańskiego resortu obrony wielokrotnie wypowiadali się jednak sceptycznie na temat zaangażowania części koalicjantów, co osłabia skuteczność prowadzonych dzialań. 
Afganistanie, Pakistanie, Bangladeszu czy Indonezji. Trafnie odzwierciedlają to słowa wypowiedziane przez sekretarza obrony USA Chucka Hagela, który stwierdził, że PI jest nie tylko zagrożeniem dla USA, ale także: „To zagrożenie dla naszych sojuszników na Bliskim Wschodzie. To zagrożenie dla Europy. To zagrożenie dla każdego państwa na świecie" (Watson, 2014).

\section{BIBLIOGRAFIA}

10 błędów, które doprowadzity do powstania i sukcesów Państwa Islamskiego (2015), dziennik.pl, 14.11.2015, http://www.wiadomosci.dziennik.pl (6.06.2016).

Barfi B. (2016), The Military Doctrine of the Islamic State and Limits of Baathist Influence, Combating Terrorism Center at West Point, http://www.ctc.usma.edu (22.06.2016).

Brisard J., Martinez D. (2016), Islamic State: The Economy-Based Terrorist Funding, Thomson Reuters Accelus, http://www.risk. thomsonreuters.com (26.01.2016).

Byman D. (2016), Comparing Al Qaeda and IS: Different goals, different targets, http://www.brookings.edu (10.01.2016).

Comby J. (2016), Zagrożenie ze strony IS większe niż stwarzane przez Al-Kaide, http://wiadomosci.wp.pl (13.03.2016).

Dawn M. (2014), ISIS: And Its Hostages ISIL/Islamic State/Daesh, Createspace.

Dodwell B., Milton D., Rassler D. (2016), The Caliphate's Global Workforce: An Inside Look at the Islamic State's Foreign Fighter Paper Trial, Combating Terrorism Center at West Point, http://www.ctc.usma.edu (20.06.2016).

Hall B. (2015), Inside ISIS. The Brutal Rise of a Terrorist Army, New York

Hanne O., Flichy de La Neuville T. (2015), Państwo Islamskie. Geneza nowego kalfatu, Warszawa.

Gaier M. (2016), From Local Actor to Global Threat, The So-Called Islamic State (IS) in Iraq and Syria, Konrad-Adenauer Stiftung International Reports - The Globalisation of Terrorism, No 1.

Gambetta D., Hertog S. (2016), Engineers of Jihad: The Curious Connection between Violent Extremism and Education, Princeton.

Global Terrorism Index 2015, Measuring and Understanding the Impact of Terrorism, Institute for Economics \& Peace, http://www.economicsandpeace.org (18.01.2016).

Izak K. (2016), Leksykon organizacji i ruchów islamistycznych, Warszawa.

Laurent S. (2014), Kallfat terroru. Kulisy dziatania Państwa Islamskiego, Warszawa.

Lukasiewicz P. (2016), Czarny sztandar nad Strefa Gazy?, „Bezpieczeństwo i Obronność”, nr 2.

McCants W. (2015), The IS Apocalypse: The History, Strategy, and Doomsday Vision of the Islamic State, New York.

Mironova V. (2016), Understanding the Changing Tactics of so-called Islamic State, „NATO Review Magazine", 15.04.2016, http://www.nato.int (17.06.2016).

Niemiecki wywiad ostrzega przed zamachami. „Zagrożenie islamskim terroryzmem większe niz w 2001 roku", http://www.newsjs.com (17.03.2016).

ONZ: Już 34 ugrupowania ekstremistyczne przysięgly wierność Państwu Islamskiemu, http://www.wiadomości.wp.pl (17.03.2016).

Operacja podbój (2016), „Forum”, 15-28.04.2016.

Park B. (2014), Five Reasons why Islamic State will be Hard to Destroy, "The Telegraph", 15.08.2014 
Relations between the European Union 2011 - determinants, areas of co-operation and prospects (2015), (eds.) A. Potyrała, B. Przybylska-Maszner, S. Wojciechowski, Berlin.

Rocznik Strategiczny 2014/2015. Przeglad sytuacji politycznej, gospodarczej i wojskowej w środowisku międzynarodowym Polski (2015), Warszawa.

Rudischhauser W. (2015), Could ISIL go nuclear?, „NATO Review Magazine”, 26.05.2015, http://www.nato.int (15.06.2016).

Shaker T. (2010), Qaeda Leaders in Iraq Neutralized, US Says, „The New York Times”, 4.06.2010.

Stownik języka polskiego (1978), (red.) M. Szymczak, Warszawa.

Todenhöfer J. (2016), ISIS od środka. 10 dni w „Państwie Islamskim”, Kraków.

Watson B. (2014), Hagel Declares ISIL Clear and 'Imminent Threat' to US, http://www.defenseone.com (10.07.2014).

Weiss M., Hassan H. (2015), ISIS. Wewnatrz armii terroru, Warszawa.

Wejkszner A. (2010), Ewolucja terroryzmu motywowanego ideologia religijna na przykladzie salafickiego ruchu globalnego dzihadu, Poznań.

Wejkszner A. (2016), Państwo Islamskie. Narodziny nowego kallfatu?, Warszawa.

Wojciechowski S. (2013), The Hybridity of Terrorism. Understanding Contemporary Terrorism, Berlin.

Wojciechowski S. (2016), Terroryzm - stary problem i nowe wyzwania, „Bezpieczeństwo i Obronność", $\mathrm{nr} 2$.

Wojciechowski S., Siadkowski A. (2014), Understanding Contemporary Terrorism and Counterterrorism, Dąbrowa Górnicza.

\title{
STRESZCZENIE
}

Zasadniczym celem tekstu jest wskazanie oraz usystematyzowanie najważniejszych przyczyn, które doprowadziły do gwałtownego wzrostu siły oraz znaczenia „Państwa Islamskiego”. Są one sumą składową wielu różnorakich i ściśle powiązanych ze sobą czynników. Można je zakwalifikować do trzech głównych grup, takich jak: A) skuteczne wykorzystanie przez „Państwo Islamskie" siły twardej związanej zarówno z działaniami militarnymi, jak i atakami terrorystycznymi; B) odpowiednie zastosowanie siły miękkiej dotyczącej na przykład sfery finansowej, logistycznej, werbunkowej czy propagandowej; C) różne wydarzenia czy procesy lokalne oraz międzynarodowe, które w większym lub mniejszym stopniu, przyczyniły się także do sukcesów PI. Powyższe trzy grupy czynników oraz zachodzące pomiędzy nimi interakcje tworzą system naczyń połączonych określany mianem triady fenomenu „Państwa Islamskiego”.

Slowa kluczowe: „Państwo Islamskie”, ISIS, terroryzm, Al-Kaida, triada fenomenu „Państwa Islamskiego"

\section{THE PHENOMENON OF „ISLAMIC STATE” AND ITS REASONS}

\begin{abstract}
The aim of the text is to present and systematize the most important reasons for the „Islamic State" dramatic rise to power and significance. The reasons are the sum total of a number of diverse and mutually linked factors. These fall into the three categories: A. effective use of hard
\end{abstract}


power connected to military activities and terrorist attacks; B. appropriate use of soft power concerning financial, logistics or propaganda sphere; C. different events of processes of local or international character. These three groups of factors and their interactions result in the so-called triad of the „Islamic State” phenomenon.

Key words: „Islamic State”, ISIS, terrorism, Al-Qaida, the triad of the „Islamic State” phenomenon 